\title{
SUITES OF FIRE-ADAPTED TRAITS OF OAKS IN THE SOUTHEASTERN USA: MULTIPLE STRATEGIES FOR PERSISTENCE
}

\author{
J. Morgan Varner ${ }^{1,6^{*}}$, Jeffrey M. Kane ${ }^{2}$, J. Kevin Hiers ${ }^{3}$, Jesse K. Kreye ${ }^{4}$, \\ and Joseph W. Veldman ${ }^{5}$ \\ ${ }^{1}$ Department of Forest Resources \& Environmental Conservation, Virginia Tech, \\ 310 W Campus Drive, Blacksburg, Virginia 24061, USA \\ ${ }^{2}$ Department of Forestry \& Wildland Resources, Wildland Fire Laboratory, \\ Humboldt State University, 1 Harpst Street, Arcata, California 95521, USA \\ ${ }^{3}$ Office of Environmental Stewardship, Sewanee: The University of the South, \\ 735 University Avenue, Sewanee, Tennessee 37383, USA \\ ${ }^{4}$ Department of Forestry, Forest \& Wildlife Research Center, Mississippi State University, \\ Box 9681, Mississippi State, Mississippi 39759, USA \\ ${ }^{5}$ Department of Ecology, Evolution, and Organismal Biology, Iowa State University, \\ 251 Bessey Hall, Ames, Iowa 50010, USA \\ ${ }^{6}$ Current address: USDA Forest Service, Pacific Northwest Research Station, \\ Pacific Wildland Fire Sciences Laboratory, \\ 400 North 34th Street, Suite 201, Seattle, Washington 98103, USA \\ *Corresponding author: Tel.: +1-206-732-7889; e-mail: julianvarner@fs.fed.us
}

\section{ABSTRACT}

Fire is integral to the functioning of terrestrial ecosystems of the southeastern USA and is a strong selective force on plant species. Among woody plants, oak species (Quercus spp. L) have diverse life history traits that appear to reflect their evolution in this fire-prone region. Oaks also occur across wide gradients of fire frequency and intensity, from annually burned savannas to fire-protected forests. As such, oak functional traits are presumed to reflect adaptations to acquire limited resources (i.e., "physiological traits") or survive environmental stress (i.e., "protective traits").

\section{RESUMEN}

El fuego es parte integral del funcionamiento de los ecosistemas terrestres del sureste de los EEUU, y también una fuerza selectiva en las especies vegetales. Entre las plantas leñosas, las especies de roble (Quercus spp. L) tienen diversas historias de vida y características que parecen reflejar su evolución en esta región propensa al fuego. Los robles también ocurren a través de amplios gradientes de frecuencias e intensidad de fuegos, desde sabanas que se queman anualmente hasta bosques protegidos del fuego. De tal modo, se presume que las características funcionales de los robles reflejan adaptaciones para adquirir recursos limitados (p.ej., características fisiológicas) o sobrevivir al estrés ambiental (características de protec- 
Oak functional traits may also influence fire regimes (i.e., via "flammability traits") by altering fire behavior through effects on fuels and their combustion. We synthesized evidence from ecophysiological measurements, laboratory burning and drying experiments, and field experiments to determine the suites of functional traits that reflect fire adaptive strategies in eight Southeastern oaks for which abundant data were available. We found strong correlations among Principal Components Analysis axes for flammability (litter burning and drying), protective (bark and wound responses), and physiological (growth) traits. The eight oaks clustered into three strategies: 1) pyrophytic species that produce highly flammable leaf litter, accrue thick bark rapidly, close wounds rapidly, and grow slowly; 2) mesophytic species that produce low flammability litter, have thin bark, and are fast growing; and 3) fire-avoider species with a mixture of traits from the two extremes. This synthesis clarifies the relative pyrophily of Southeastern oaks and suggests how suites of fire-related traits influence fire regimes and species habitat preferences. ción). Las características funcionales de los robles también pueden influenciar los regímenes de fuego (p.ej., vía características de inflamabilidad) mediante la alteración del comportamiento del fuego a través del efecto de los combustibles y su combustión. Nosotros sintetizamos evidencias tomadas de mediciones ecofisiológicas, quemas en laboratorio y experimentos de campo para determinar los grupos de características funcionales que reflejen las estrategias adaptativas al fuego en ocho robles del sureste sobre los cuales existían abundantes datos. Mediante el Análisis de Componentes Principales, encontramos correlaciones muy fuertes entre los ejes que expresan inflamabilidad (sequía y quema de la hojarasca), protección (por corteza y respuestas a heridas por fuego), y características fisiológicas (crecimiento). Los ocho robles se agruparon en tres estrategias: 1) especies pirófilas que producen hojarasca altamente inflamable, acumular una gruesa corteza rápidamente, cierran las heridas prontamente, y crecen lentamente; 2) especies mesofíticas que producen una hojarasca poco inflamable, tienen una corteza fina, y crecen rápidamente; y 3) especies que evitan el fuego, con una mezcla de características de los dos extremos. Esta síntesis clarifica la pirología relativa de los robles del sureste y sugiere cómo los grupos con características similares en relación al fuego influencian los regímenes de fuego y las preferencias de hábitats por parte de estas especies.

Keywords: bark thickness, fire regimes, fuel moisture, functional traits, litter flammability, Quercus, trait associations

Citation: Varner, J.M., J.M. Kane, J.K. Hiers, J.K. Kreye, and J.W. Veldman. 2016. Suites of fire-adapted traits of oaks in the southeastern USA: multiple strategies for persistence. Fire Ecology 12(2): 48-64. doi: 10.4996/fireecogly.1202048

\section{INTRODUCTION}

Woody plants have developed a diversity of traits to decrease their susceptibility to fires, including investments in bark, responses to wounding, resprouting, storage or "banking" of seeds, and cued germination of seeds, among a host of other fire-adapted traits (Landers 1991, Bond and van Wilgen 1996, Keeley and Zedler 1998, Jackson et al. 1999, Smith and Sutherland 1999). Increasingly, we suspect that these protective and persistence traits do not occur in isolation, but rather are integrally related to the role that plants play as 
producers of fuels that influence ignition and spread of fire (Mitchell et al. 2009, Varner et al. 2015a).

To promote persistence in fire-prone ecosystems, woody plants employ multiple strategies that presumably reflect past selective pressures in suites of fire-adapted traits. The concept of "fire adapted strategies" has been covered in detail elsewhere (see Rowe 1983, Agee 1993, Bond and van Wilgen 1996), but in general, woody plant traits associated with fire can be categorized broadly into those that (1) enable survival of above-ground stems, (2) rely on resprouting of above-ground stems from bud banks, (3) rely on soil or crown seed banks, or (4) lack traits to survive fire (Agee 1993, Keeley and Zedler 1998; Figure 1). Flammability traits have been similarly categorized (Fonda 2001), with species coarsely classified as those that promote or facilitate high intensity surface fires and those that dampen, diminish, or extinguish surface fires (Kane et al. 2008, Kreye et al. 2013, Mola et al. 2014). The combination of these seemingly contradictory traits (self-protection and promotion of fire) has been evaluated in Pinus spp. L. (Keeley and Zedler 1998, Schwilk and Ackerly 2001) and suggested more widely with other taxa (Bond and Midgley 1995, Gagnon et al. 2010). Trait correlation in these cases suggests that species use multiple traits or "suites of adapted traits" to persist and increase in abundance in fire-prone landscapes.

The southeastern USA is a region with a long history of frequent fire regimes with corresponding high plant diversity (Peet 2006, Noss et al. 2015). Prior to European settlement, fire regimes were typified by frequent fires (fire return intervals $1 \mathrm{yr}$ to $10 \mathrm{yr}$ ) across many upland ecosystems dominated by a diversity of Pinus, Quercus spp. L. (hereafter “oak"), and other woody plants (Platt 1999, Stambaugh et al. 2011). Globally, many species of oak possess fire-adapted traits (Abrams 1992, Vázquez et al. 2002, Curt et al. 2011, Engber and Varner 2012), but many fire-intol- erant species exist as well. In eastern North America, oaks are dominant members of a wide range of fire-prone and fire-free communities (Abrams 1990, Dey 2002, Van Lear and Brose 2002, Nowacki and Abrams 2008). In the southeastern USA, oaks show strong affinities for fire regimes (Cavender-Bares et al. 2004b, Peet 2006, Hiers et al. 2014), suggestive of at least two broad classes: fire tolerant "pyrophytes" and fire sensitive "mesophytes" (Kane et al. 2008, Hiers et al. 2014). Trait correlations have been evaluated for pines in the southeastern USA (Landers 1991, Keeley and Zedler 1998), for physiological trait correlations in southeastern USA oaks (Cavender-Bares et al. 2004b), and for growth and reproduction in the central USA oaks (Guyette et al. 2004).

Of the approximately 90 oak species in the USA, the southeastern region harbors approximately 30 species that span wide ecological gradients of soil moisture availability, tree canopy density, fire frequency, and fire intensity (Jacqmain et al. 1999, Kirkman et al. 2007). Southeastern oaks have wide variation in fire adapted traits, including their rates of bark accumulation, absolute bark thickness, response to stem injury, and litter drying and burning characteristics (Jackson et al. 1999, Kane et al. 2008, Romero et al. 2009, Kreye et al. 2013, Graves et al. 2014). Of the diversity of Southeastern oaks, sufficient data exist for only eight species (Table 1). No formal work has been conducted to date that evaluates the interrelationships among fire-adapted traits in Southeastern oaks.

In this study, we evaluated the relationships among functional traits in eight Southeastern oak species and identified potential multi-trait strategies. We incorporated data from six oak datasets that include either fire-related traits or physiological traits that may contribute to persistence in fire-prone communities (Table 2). We hypothesized that fire protective traits in oaks (e.g., thick bark, wound closure) would correlate with flamma- 


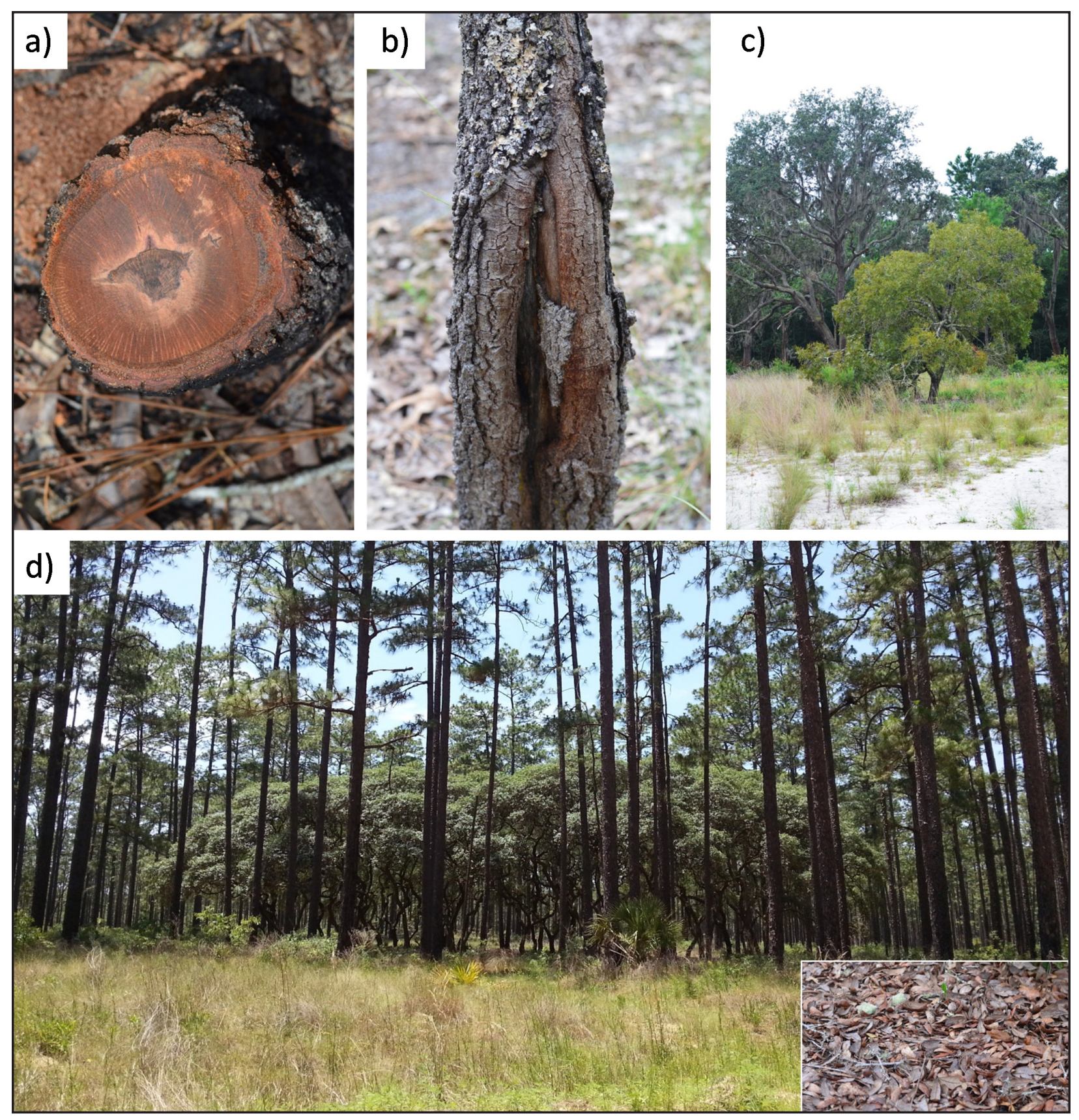

Figure 1. Oak traits associated with persistence in fire-prone ecosystems. Thick bark (a), rapid wound closure (b), and short stature (c) of Quercus laevis Walter. (d) Localized differences in litter characteristics (moisture enhancing and less flammable; see inset) beneath a Q. geminata Small "dome."

bility traits that facilitate fire (e.g., rapid litter drying rates, high litter fire intensity). Further, we hypothesized that physiological traits that confer advantages for growth would be sacrificed in lieu of investment in traits that protect oaks and facilitate fire. Our findings should add to the understanding of tradeoffs in functional traits that can confer advantages to oaks in fire-prone ecosystems of the southeastern USA and perhaps more broadly, in regions in which diverse woody species interact with fire. 
Table 1. Southeastern USA Quercus species discussed in this paper. Community classification is from Hiers et al. (2014).

\begin{tabular}{llll}
\hline Scientific name & Common name & Clade & Community \\
\hline Quercus falcata Michx. & southern red oak & red & pyric to mesic uplands \\
Q. geminata Small & sand live oak & live & pyric uplands \\
Q. hemisphaerica W. Bartr. ex. Willd. & laurel oak & red & mesic hammocks \\
Q. incana W. Bartr. & bluejack oak & red & pyric uplands \\
Q. laevis Walter & turkey oak & red & pyric uplands \\
Q. margaretta (Ashe) Small & sand post oak & white & pyric uplands \\
Q. nigra L. & water oak & red & mesic hammocks \\
Q. virginiana Mill. & live oak & live & mesic hammocks \\
\hline
\end{tabular}

\section{METHODS}

\section{Oak Trait Data Sources}

We used published data on traits for eight native southeastern USA oak species (Table 1). These species were selected based on the availability of data for the traits we examined (Table 2). The eight species span gradients in stature (from small to large trees), leaf lifespan, longevity, apparent site preferences (mesic to xeric), and represent the phylogenetic diversity of the genus, including species from the white, red, and live oak clades (Cavender-Bares et al. 2004a, b).

The trait data we used were gathered from a variety of published sources (Table 2). Oak litter depth and burning data (flame height, flaming duration, smoldering duration, and fuel consumption) were taken from Kane et al. (2008) and Varner et al. (2015b). Oak litter drying data (drying time and moisture holding capacity) were taken from Kreye et al. (2013) and Mola et al. (2014). Oak bark thickness and wounding response data were derived from Jackson et al. (1999) and Romero et al. (2009) and include the following variables: bark accumulation rate (as phloem coefficient), sapling and mature oak rhytidome thickness, maximum bark thickness, sapling wound closure rate, the area of xylem lost from wounding and decay, and measures of sapling total and inner bark rhytidome thickness. To relate known fire-adapted traits to potentially fire-related physiological traits, we used oak physiological data from Cavender-Bares et al. (2004b) including asymptotic tree height, seed mass, leaf lifespan, duration of canopy (days with leaves in the crown), laminar leaf area, specific leaf area (SLA), maximum $\mathrm{CO}_{2}$ assimilation rate based on leaf area $\left(\mathrm{A}_{\max }\right)$ and leaf mass $\left(\mathrm{A}_{\text {mass }}\right)$, leaf $\mathrm{N}$ (nitrogen), leaf chlorophyll, maximum hydraulic conductance $(\max \mathrm{Ks})$, absolute seedling growth rate, seedling relative growth rate, radial growth increment, wood density, sapwood per leaf area (Huber), and percent loss of conductivity (Table 2).

\section{Data Analysis}

Because of the number of traits and known correlations within trait groups (protective [Romero et al. 2009], flammability [Varner et al. 2015a], and physiological [Cavender-Bares et al. 2004b]), we used a tiered multivariate approach in our analyses. We first conducted a trait correlation analysis across all available species to examine how traits within the same trait group (flammability, protective, and physiological) were related. We then conducted a cluster analysis to examine how species 
Table 2. List of potential fire-adapted traits in Southeastern Quercus and data sources.

\begin{tabular}{|c|c|}
\hline $\begin{array}{lc}\text { Trait grouping } \\
\end{array}$ & Data sources \\
\hline $\begin{array}{l}\text { Flammability traits (units) } \\
\text { Litter flame height }(\mathrm{cm}) \\
\text { Litter flaming duration }(\mathrm{sec}) \\
\text { Litter smoldering duration }(\mathrm{sec}) \\
\text { Fuel consumption }(\%) \\
\text { Litter depth }(\mathrm{cm}) \\
\text { Litter drying rate }(\mathrm{hr}, \text { timelag) } \\
\text { Litter absorptive capacity }(\%) \\
\end{array}$ & $\begin{array}{l}\text { Kane et al. 2008, } \\
\text { Kreye et al. 2013, } \\
\text { Varner et al. 2015b }\end{array}$ \\
\hline $\begin{array}{l}\text { Protective traits (units) } \\
\text { Rhytidome thickness }(\mathrm{cm}) \\
\text { Phloem allometric coefficient (accumulation rate; unitless) } \\
\text { Sapling rhytidome thickness }(\mathrm{cm}) \\
\text { Adult rhytidome thickness }(\mathrm{cm}) \\
\text { Wound closure }(\%) \\
\text { Xylem area lost }\left(\mathrm{cm}^{2}\right) \\
\text { Xylem vertical (up+down) decay (cm) } \\
\text { Inner bark }(\%)\end{array}$ & $\begin{array}{l}\text { Jackson et al.1999, } \\
\text { Romero et al. } 2009\end{array}$ \\
\hline 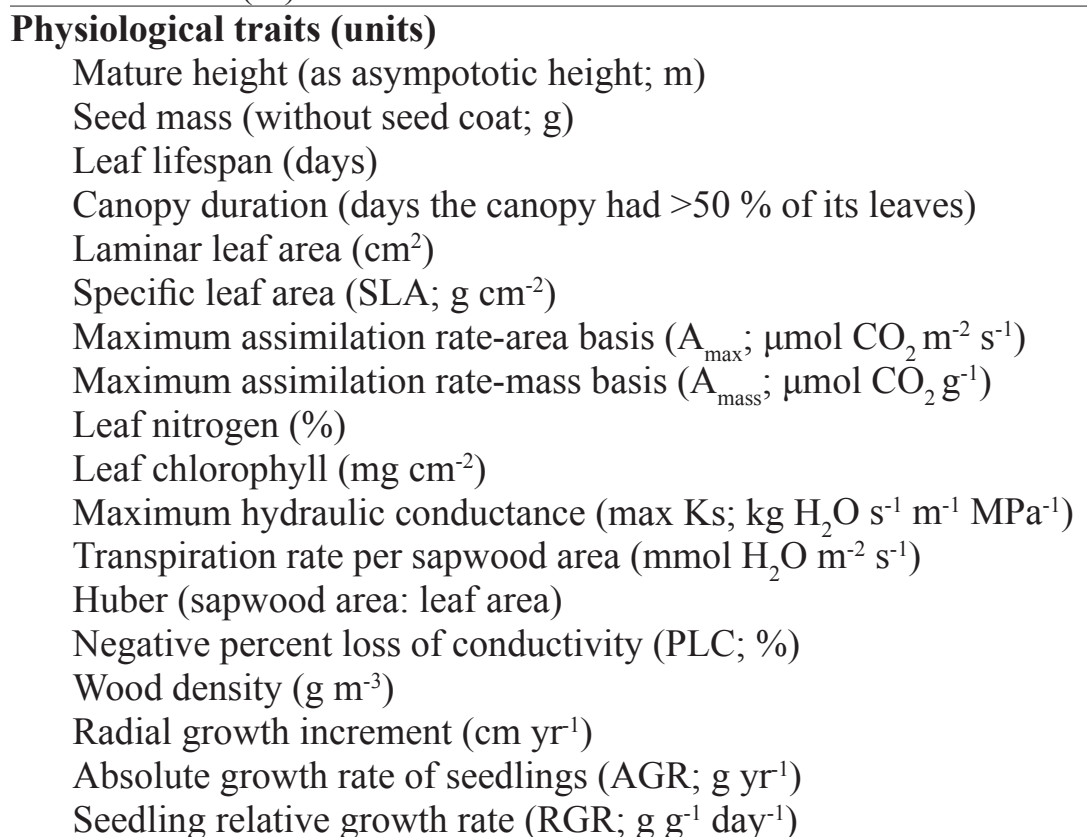 & Cavender-Bares et al. $2004 a$ \\
\hline
\end{tabular}

grouped according to their suite of traits. A1though flammability, protective, and physiological trait data were available for the eight Southeastern oak species of interest, the complete set of 33 traits examined were not available for all species. For our trait correlation analysis, we reduced our dataset to five species (Q. laevis, $Q$. falcata, Q. incana, Q. nigra, and Q. virginiana) to evaluate relationships across all traits. For our cluster analysis, we reduced our dataset to 25 traits in order to examine groupings across all eight species. The trait correlation analysis allowed us to determine which traits could be removed for cluster analysis without losing information.

\section{Trait Correlation Analysis}

For each group of traits (flammability, protective, and physiological), we used Principal 
Components Analysis (PCA). The PCA is a multivariate statistical approach that reduces dimensionality (the number of variables) and minimizes potential multicollinearity (enabling subsequent analyses) among traits (Gotelli and Ellison 2013). In each PCA, we retained the number of axes needed to explain at least $80 \%$ of the variation in each dataset (Afifi et al. 2004). We subsequently compared the relationships among trait groupings via correlations between factor scores from each of the retained protective, flammability, and physiological trait axes. In resulting comparisons, we discuss all axis relationships with $\mathrm{r} \geq$ 0.60 .

\section{Cluster Analysis}

To evaluate the suites of traits among the group of eight oaks, we used a PCA to reduce dimensionality of the 25 traits available for all eight species and subsequently conducted a cluster analysis, by species, using the resulting flammability, protective, and physiological PCA axes. To determine the optimum number of clusters, we used fuzzy agglomerative clustering in which the full dataset is iteratively combined to generate smaller numbers of clusters (Gotelli and Ellison 2013). Results were plotted in a dendrogram across a Euclidean distance to highlight relatedness. The goodness-of-fit in fuzzy agglomerative clustering uses the normalized Dunn's partition coefficient $(F c[U])$ where $F c(U)$ varies from 0 (completely fuzzy) to 1 (hard cluster) while minimizing the normalized partition coefficient $D c(U)$ (Kaufman and Rousseeuw 2005). All analyses were performed using NCSS version 9 (NCSS Statistical Software, Kaysville, Utah, USA).

\section{RESULTS}

\section{Trait Correlation Analysis}

Correlations among the individual litter flammability (burning and drying) traits re- vealed several similar patterns. The PCA of the four burning, two drying, and litter depth traits for the eight oak species resulted in a two axis solution that explained $80.1 \%$ of variation in the dataset (Appendix 1). The first axis ("Flam 1" hereafter) explained $60.9 \%$ of the data and was negatively related to flaming duration and drying time, but positively related to flame height, fuel consumption, and litter depth. The second axis ("Flam 2") explained an additional $19.2 \%$ of the variation and was positively related to smoldering duration, litter drying rate, and litter moisture capacity. Individual flammability traits were highly correlated. In general, species with deep (i.e., more porous) litter dried quickly, burned with tall flames, burned for a short duration, and consumed most of its fuel.

Our PCA for protective traits (bark accumulation, wound responses, and mature height) also followed consistent patterns. The PCA resulted in a two-axis solution that explained $81.3 \%$ of the nine-trait dataset. The first axis ("Bark 1") explained $65.2 \%$ of the data and was positively related to bark rhytidome thickness, sapling rhytidome thickness, and wound closure rates, and negatively related to mature height, xylem loss and decay, and overall rhytidome thickness. The second axis ("Bark 2") explained an additional $16.1 \%$ of the trait data and was positively related to inner bark rhytidome. Not surprisingly, most of the individual traits were highly correlated with each other: species with thick and rapidly accumulating bark tended to repair wounds rapidly and had minimal decay of exposed tissues. Mature oak height was negatively related to sapling rhytidome and wound closure rates and positively related to xylem area lost following wounding.

The combination of the 17 physiological traits resulted in a three-axis PCA solution that explained $82.9 \%$ of this dataset. The first axis ("Phys 1") explained $42.8 \%$ of the physiological trait data and was positively related to SLA, laminar leaf area, and transpiration rates, and negatively related to leaf lifespan, canopy 
duration, $\mathrm{A}_{\max }$, Huber (leaf area:sapwood area), wood density, and seedling relative growth rates. The second axis ("Phys 2") explained $25 \%$ of the dataset and was positively related to max Ks, transpiration rates, conductivity loss, and seedling average growth rates. The third axis ("Phys 3") explained an additional $15.1 \%$ of the 17-trait dataset and was positively related to measures of photosynthesis $\left(\mathrm{A}_{\max }\right.$ and $\left.\mathrm{A}_{\text {mass }}\right)$.

When the trait PCA axes are compared, relationships are apparent between protective, flammability, and physiological trait groups (Table 3). Flam 1, the first PCA of flammability traits, was positively related $(r=0.67)$ to the first PCA of protective traits, Bark 1. Flam 1 was also positively related $(\mathrm{r}=0.84)$ to Phys 1. Bark 1 was positively related $(r=0.79)$ to Phys 1 . Species with flammable litter also develop thick bark and rapidly close wounds, but showed an associated tradeoff of slower growth with the primary protective and flammability trait axes. Individual trait comparisons emphasize tradeoffs (Figure 2).

\section{Cluster Analysis}

The cluster analysis of the flammability, protective, and physiological PCA axes, using the 25 traits highlighted in Table 2, segregated the eight oak species into three clusters (Fig-

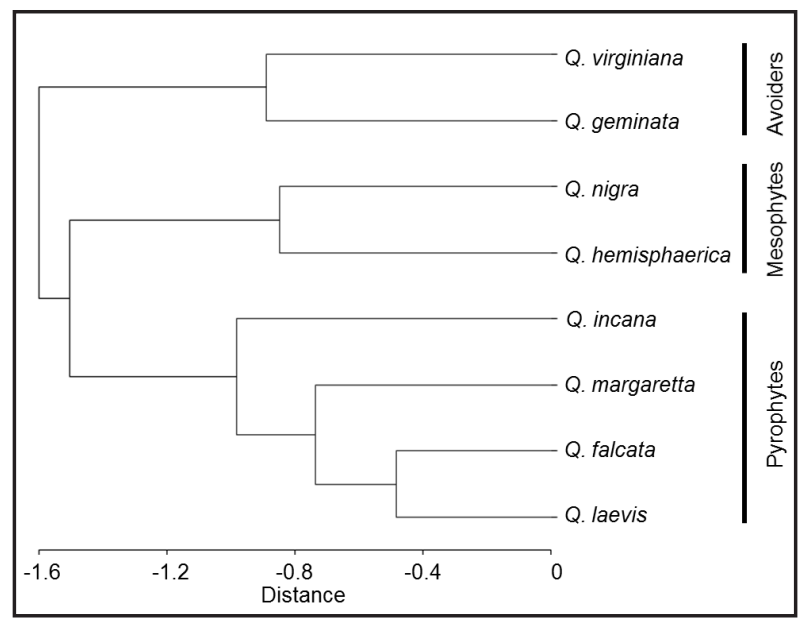

Figure 2. Dendrogram of eight southeastern USA oaks based on a cluster analysis of PCA axes for flammability, protective, and physiological traits. "Distance" refers to Euclidean distance.

ure 3). The first cluster (hereafter "pyrophytes") contained the deciduous $Q$. laevis, $Q$. margaretta, Q. incana, and Q. falcata. These pyrophytic species share high flammability and rapid bark accumulation, but potentially slower growth. The second cluster (hereafter "mesophytes") contained the brevideciduous (long leaf lifespan) forest trees $Q$. hemisphaerica and $Q$. nigra, characterized by low flammability, thin bark, weak wound responses, but rapid growth rates. The third cluster (hereafter "avoiders") contained the evergreen

Table 3. Relationships between protective, flammability, and physiological trait principal components analysis axes. Flam 1 and Flam 2 correspond to the first and second axes of flammability (litter burning and drying), respectively. Bark 1 and Bark 2 correspond to the first and second axes of protective traits (bark and wound response), respectively. Phys 1, Phys 2, and Phys 3 correspond to the first, second, and third axes of physiological traits, respectively. Values in columns are correlation coefficients (r).

\begin{tabular}{|c|c|c|c|c|c|c|c|}
\hline \multicolumn{8}{|c|}{ Trait PCA } \\
\hline Trait PCA & Flam 1 & Flam 2 & Bark 1 & Bark 2 & Phys 1 & Phys 2 & Phys 3 \\
\hline Flam1 & & 0.00 & 0.67 & 0.16 & 0.84 & -0.47 & -0.09 \\
\hline Flam 2 & & & 0.47 & 0.54 & 0.22 & 0.10 & 0.37 \\
\hline Bark 1 & & & & 0.08 & 0.79 & 0.35 & 0.37 \\
\hline Bark 2 & & & & & 0.28 & 0.26 & 0.28 \\
\hline Phys 1 & & & & & & 0.00 & 0.00 \\
\hline Phys 2 & & & & & & & 0.00 \\
\hline Phys 3 & & & & & & & \\
\hline
\end{tabular}




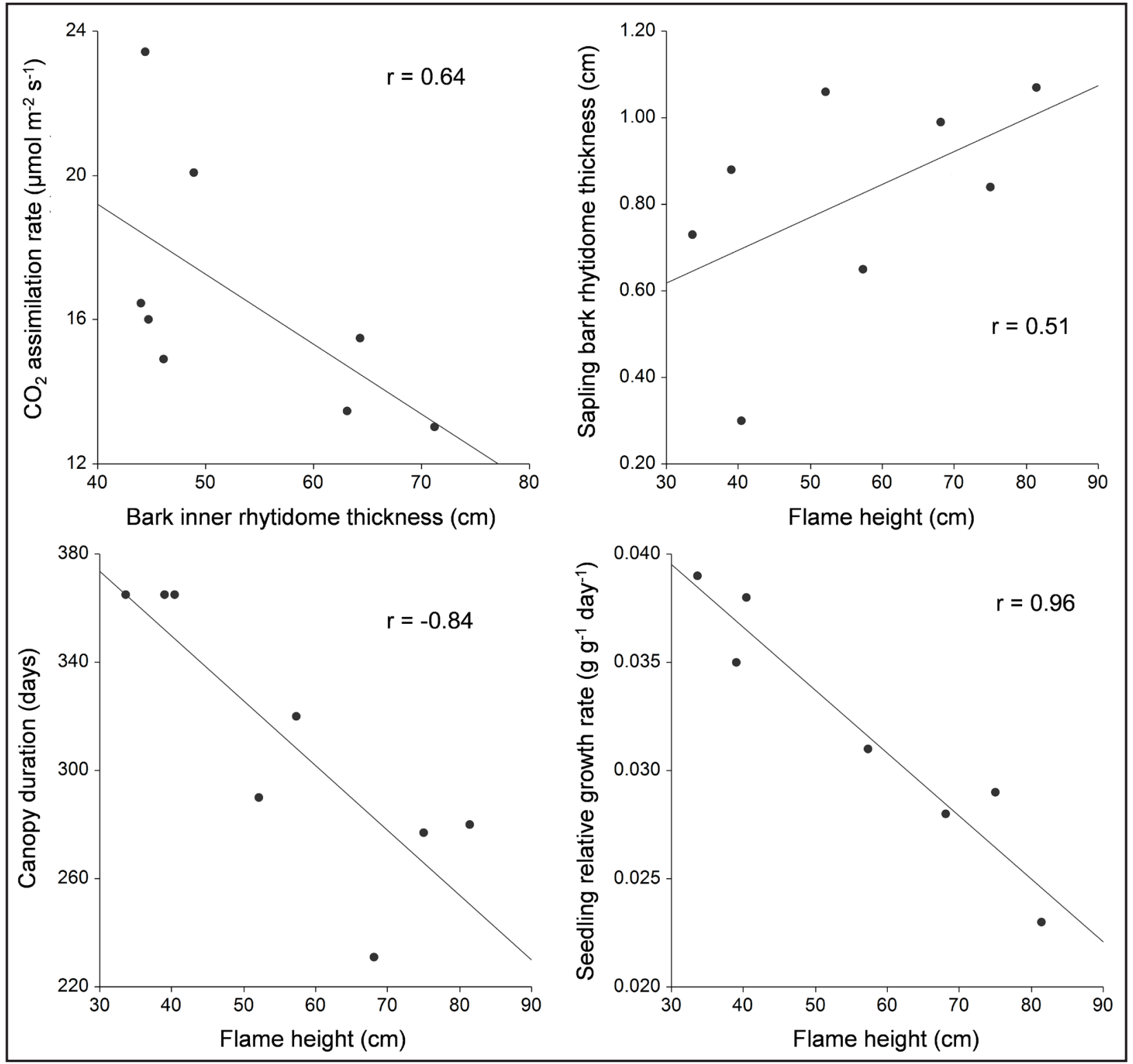

Figure 3. Correlations between flammability (litter flame height), protective (sapling inner bark rhytidome), and physiological (seedling relative growth rates and canopy duration) traits for eight Southeastern oaks.

live oaks $Q$. geminata and $Q$. virginiana that have low flammability, accumulate thick bark when mature, and have rapid growth rates and high wood density.

\section{DISCUSSION}

Oaks inhabit a diversity of sites across the southeastern US, exhibiting numerous fire-related protective, flammability, and physiologi- cal traits (Jacqmain et al. 1999, Cavender-Bares et al. 2004b). For oaks that are abundant in fire-prone pine-oak savannas and woodlands, the pyrophytes, there are clear advantages for traits that promote ecosystem flammability and protect stems from heating, despite reduced growth potential (Kane et al. 2008, Veldman et al. 2013). Oaks that lack fire protective and flammability traits, the mesophytic species, tend to co-dominate in for- 
ests (in contrast to savannas or woodlands) in which competition for light is acute and the probability of fires is reduced (Veldman et al. 2013). These mesophytic oaks have traits that confer rapid height growth, at the cost of developing traits that facilitate survival in frequently burned environments (Cavender-Bares et al. 2004b). Frequent fires should favor pyrophytes while infrequent fires or fire exclusion should favor mesophytes (Platt and Schwartz 1990, Kane et al. 2008, Nowacki and Abrams 2008, Beckage et al. 2009, Mola et al. 2014). Indeed, our analyses suggest that tradeoffs (negative correlations) between flammability and protective traits and acquisitive physiological traits, as well as suites of positively correlated flammability and protective traits (Figure 3) underlie observed suites of adapted traits and habitat preferences in oaks (Hiers et al. 2014).

Traits that confer advantages to oaks in fire-prone sites represent the pyrophyte model (Hiers et al. 2014). Pyrophytes in our analysis possessed protective traits such as rapid juvenile bark accumulation (Jackson et al. 1999, Graves et al. 2014, Hammond et al. 2015) and rapid wound closure (Romero et al. 2009). Traits that promote flammability may enable pyrophytic oaks to increase local fire intensity while also injuring neighboring invaders that lack protective bark and wounding responses (Bond and Midgley 1995, Kane et al. 2008, Gagnon et al. 2010). The pyrophytes that invest in protective and flammability traits apparently do so through tradeoffs in growth rates (Table 3, Figure 2) as has been observed in other Southeastern savanna-woodland trees (Hammond et al. 2015). Southeastern pyrophytes that use these strategies include $Q$. laevis, Q. margaretta, Q. falcata, and $Q$. incana. Although we lacked complete data for $Q$. marilandica Münchh., Q. stellata Wangenh., and $Q$. alba L., their flammability and protective traits (Hammond et al. 2015, Varner et al. 2015b) are consistent with this pyrophytic strategy. This suite of traits enables pyrophyt- ic oaks to predominate over a wide range of fire-prone landscapes in the southeast and potentially more broadly across eastern North America (Abrams 1996, Jacqmain et al. 1999, Guyette et al. 2004, Veldman et al. 2013).

An alternative fire strategy is typified by the mesophytic oaks, which enables them to invade formerly fire-prone sites and, where established, to resist invasion by pyrophytes. These species impede rather than promote fire, and also lack protective adaptations that would allow persistence following fire (Figure 2). In frequently burned landscapes, these species dominate in fire-protected refugia (Platt and Schwartz 1990, Ware et al. 1993, Mola et al. 2014); where they are present in pyric uplands, these species are uncommon, short-lived, or persist as resprouts (e.g., Grady and Hoffmann 2012). Where fires are excluded, their dominance increases, often resulting in changes to community flammability and drastic shifts in community composition and structure, all of which are characterized by the positive feedback phenomenon termed "mesophication" (Nowacki and Abrams 2008). In addition to the lack of flammability and protective traits, these species grow rapidly (Figure 2) and have long leaf lifespans. In the southeastern USA, mesophication begins when fire-sensitive species establish during fire-free intervals and proliferate as fire is further excluded (Gilliam and Platt 1999). The consequences of fire exclusion for pyrogenic communities can be severe, with dramatic reductions in plant and animal biodiversity (e.g., Engstrom et al. 1984, Ware et al. 1993, Gilliam and Platt 1999, Hiers et al. 2007), as well as novel outcomes for remnant pyrophytic species when fire is reintroduced (e.g., fire-caused death of normally fire-resistant trees; Varner et al. 2005). The mesophytic oaks in our dataset were $Q$. nigra and Q. hemisphaerica (as in Kane et al. 2008, Kreye et al. 2013). These mesophytic oaks cause functional changes to pine-oak savannas that are similar to the changes attributed to maples (Acer rubrum L. and A. saccharum 
Marshall) in fire-excluded Eastern deciduous forests (Nowacki and Abrams 2008, Stambaugh et al. 2015). These mesophytic oaks (but not pyrophytes) should be primary targets for removal in ecological restoration of pineoak woodlands in the region, yet many managers mistakenly target all oaks, due to a failure to recognize the functional roles of pyrophytes (Hiers et al. 2014). Our results emphasize the fire-related strategies of the pyrophytic Southeastern oaks and should help clarify management that discriminates these species.

Beyond these pyrophyte or mesophyte groupings, other oaks survive in fire-prone environments via alternative strategies. This third group we term avoiders (sensu Rowe 1983), which persist by casting non-flammable litter (via their retention of moisture or via diminished fire intensity when they do ignite) and by casting evergreen shade and deep litter that further diminish herbaceous fuels in localized patches (Hiers et al. 2007, Kane et al. 2008, Kreye et al. 2013). Cumulatively, these changes in local fuels diminish or extinguish fires in close proximity to individual trees or small clumps. The classical examples of this protective strategy are oak "domes" of $Q$. geminata that persist within frequently burned Southeastern pine-oak savannas (Figure 1; Guerin 1993), and the lake-margin Q. virginiana forests that intermix with frequently burned uplands (Cavender-Bares et al. 2004a). This same localized positive feedback pattern can be found in other fire-prone savannas (Engber et al. 2011, Trauernicht et al. 2012). There still exists a need to determine the traits that allow these otherwise fire-susceptible oaks to persist in fire-prone landscapes (Hiers et al. 2014).

For a fuller understanding of how oak functional traits influence ecosystem flammability and tree community composition, we must consider not just the trees themselves but also their relationships with the characteristic herbaceous understories of savannas and woodlands (e.g., Scholes and Archer 1997,
Engber et al. 2011). Fires in savannas and woodlands are fueled by a mixture of flammable grasses and forbs and to a lesser extent by scattered tree litter and scant woody fuels (Engber et al. 2011). The variation in individual species effects on surrounding herbaceous fuels is not well understood, although it is known that southeastern USA species of the same stature allow different quantities and qualities of light to reach the forest floor (Battaglia et al. 2003, Pecot et al. 2007). The relationships we presented between canopy duration and the suites of physiological, protective, and flammability traits suggest that pyrophytes may promote ecosystem flammability not only by producing flammable litter, but through the indirect effects on herbaceous fuel productivity (Hoffmann et al. 2012). Indeed, field studies suggest that, compared to mesophytic oaks, pyrophytes in the southeastern USA are better able to coexist with flammable C4 grasses, thereby promoting ecosystem flammability, limiting the abundance of fire-sensitive tree species, and maintaining high-light environments (Veldman et al. 2013). The mechanisms by which pyrophytes coexist with herbaceous plant communities remains unclear, but likely involve many of the functional traits considered in this study, including long canopy duration (i.e., low understory light penetration) and highly flammable litter (Figure 3; e.g., Hiers et al. 2007, Kane et al. 2008). Still, we need to know more about the relationships between canopy light transmittance (Battaglia et al. 2003, Engber et al. 2011), understory competition (Harrington 2011, Veldman et al. 2013), and vegetation-fire feedbacks (Beckage et al. 2009, Mitchell et al. 2009, Fill et al. 2015) to fully understand how oak fire survival strategies relate to the long-term functioning of these ecosystems.

One important fire-adapted trait that we did not include in our analysis is post-fire sprouting. Though some research has focused on Southeastern oak resprouting (Robertson and Ostertag 2009, Robertson and Hmielowski 
2014, Hammond et al. 2015), a comprehensive study has not yet been conducted for the species in our analysis. Differential sprout vigor among co-occurring oaks is likely to be common, but is a rarely reported phenomenon in the southeastern USA (Robertson and Ostertag 2009, Robertson and Hmielowski 2014, Hammond et al. 2015). Rapid sprout height growth and early fruiting of these oaks may enable them to reach reproductive size or invest in below-ground reserves for recovery following recurrent fires. In spite of the obvious advantages of rapid and vigorous sprouting in fireprone sites (Bond and Midgley 2001), there is much to learn about sprout dynamics in Southeastern oaks and other fire-prone taxa.

The apparent growth tradeoffs that we found with protective traits suggest that there are substantial physiological costs of these fire-linked traits. Indeed, the cost of allocation of resources to protective traits is well known; for example, bark is expensive (Bloom et al. 1985). The other protective traits related to wound closure and losses to decay (Table 3) suggest suites of linked traits. Beyond the traits that we evaluated, there are other documented examples of tradeoffs between bark accumulation and height growth of post-fire sprouts (Hammond et al. 2015), in which sprouts with thick bark are shorter than sprouts that allocate comparatively less to bark. This steep tradeoff may help explain the patterns of bark accumulation concentrated on the lower stem (Graves et al. 2014, Hammond et al. 2015). Where heating is greatest, investments in bark are advantageous; as heating dissipates with height, less bark is needed to protect vascular cambia and stemwood.

The relationships that we observed between protective, flammability, and physiolog- ical traits are promising given the few species for which comprehensive data were available for our analysis. With these initial findings, expanding this dataset to other oak species (e.g., Guyette et al. 2004) should provide greater clarity of how traits define these fire survival strategies and potentially identify others. Linking these traits to patterns in species presence and abundance across fire-prone landscapes is a logical next step (Guyette et al. 2004, Veldman et al. 2013).

The southeastern USA oaks use a wide spectrum of traits that facilitate their persistence in fire-prone savannas and woodlands. Understanding these suites of traits will enable managers to better design management to ensure their persistence as well as their importance in ecosystem function and as drivers of animal and plant biodiversity (Hiers et al. 2014). Incorporating flammability, protective, and physiological traits into a comprehensive analysis provides insight into the tradeoffs inherent to species strategies for persistence in fire-prone environments. Through the exposure of complex interactions between litter-driven fire behavior, protective traits, and physiological responses to fire, this work furthers our understanding of the dynamic feedback between plants as fuel for fire and their capacity to survive and affect future fire behavior (Mitchell et al. 2009, Fill et al. 2015). Most studies emphasize the importance of particular traits with clear associations with fire; however, we highlight that less intuitive traits are also essential and that multiple strategies contribute to persistence in fire-prone ecosystems (as in Schwilk et al. 2013). A better understanding of these traits and strategies is needed to manage and promote biodiversity in these and other fire-prone ecosystems.

\section{ACKNOWLEDGEMENTS}

E. Engber, S. Brewer, C. Romero, M. Cocking, M. Hiss, and F.E. Putz have helped our thinking on oaks, fire, and trait syndromes in general. We acknowledge funding from the Joint Fire Science Program under project JFSP 13-1-04-49. This paper represents contribution AAOS2016-01. 


\section{LITERATURE CITED}

Abrams, M.D. 1990. Adaptations and responses to drought in Quercus species of North America. Tree Physiology 7: 227-238. doi: 10.1093/treephys/7.1-2-3-4.227

Abrams, M.D. 1992. Fire and the development of oak forests. BioScience 42: 346-353. doi: $10.2307 / 1311781$

Abrams, M.D. 1996. Distribution, historical development and ecophysiological attributes of oak species in the eastern United States. Annals of Forest Science 53: 487-512. doi: 10.1051/ forest: 19960230

Afifi, A., V.A. Clark, and S. May. 2004. Computer-aided multivariate analysis. Fourth edition. Taylor and Francis, Boca Raton, Florida, USA.

Agee, J.K. 1993. Fire ecology of Pacific Northwest forests. Island Press, Washington, D.C., USA.

Battaglia, M.A., R.J. Mitchell, P. Mou, and S.D. Pecot. 2003. Light transmittance estimates in a longleaf pine woodland. Forest Science 49: 752-762.

Beckage, B., W.J. Platt, and L.J. Gross. 2009. Vegetation, fire, and feedbacks: a disturbance-mediated model of savannas. The American Naturalist 174: 805-818. doi: 10.1086/648458

Bloom, A.J., F.S. Chapin, and H.A. Mooney. 1985. Resource limitation in plants-an economic analogy. Annual Review of Ecology and Systematics 16: 363-392. doi: 10.1146/annurev. es.16.110185.002051

Bond, W.J., and J.J. Midgley. 1995. Kill thy neighbour: an individualistic argument for the evolution of flammability. Oikos 73: 79-85. doi: 10.2307/3545728

Bond, W.J., and J.J. Midgley. 2001. Ecology of sprouting in woody plants: the persistence niche. Trends in Ecology \& Evolution 16: 45-51. doi: 10.1016/S0169-5347(00)02033-4

Bond, W.J., and B.W. van Wilgen. 1996. Fire and plants. Population and Community Biology Series 14. Chapman \& Hall, London, England, United Kingdom.

Cavender-Bares, J., D.D. Ackerly, D.A. Baum, and F.A. Bazzaz. 2004a. Phylogenetic overdispersion in Floridian oak communities. The American Naturalist 163: 823-843. doi: $10.1086 / 386375$

Cavender-Bares, J., K. Kitajima, and F.A. Bazzaz. 2004b. Multiple trait associations in relation to habitat differentiation among 17 Floridian oak species. Ecological Monographs 74: 635662. doi: 10.1890/03-4007

Curt, T., A. Schaffhauser, L. Borgniet, C. Dumas, R. Estève, A. Ganteaume, M. Jappiot, W. Martin, A. N'Diaye, and B. Poilvet. 2011. Litter flammability in oak woodlands and shrublands of southeastern France. Forest Ecology and Management 261: 2214-2222. doi: 10.1016/j. foreco.2010.12.002

Dey, D. 2002. Fire history and postsettlement disturbance. Pages 46-59 in: W.J. McShea and W.M. Healy, editors. Oak forest ecosystems - ecology and management for wildlife. Johns Hopkins University Press, Baltimore, Maryland, USA.

Engber, E.A., J.M. Varner, L. Arguello, and N. Sugihara. 2011. The effects of conifer encroachment and overstory structure on fuels and fire in an oak woodland landscape. Fire Ecology 7(2): 32-50. doi: 10.4996/fireecology.0702032

Engber, E.A., and J.M. Varner. 2012. Patterns of flammability of the California oaks: the role of leaf traits. Canadian Journal of Forest Research 42: 1965-1975. doi: 10.1139/x2012-138

Engstrom, R.T., R.L. Crawford, and W.W. Baker. 1984. Breeding bird populations in relation to changing forest structure following fire exclusion: a 15-year study. The Wilson Bulletin 96: 437-450. 
Fill, J.M., W.J. Platt, S.M. Welch, J.L. Waldron, and T.A. Mousseau. 2015. Updating models for restoration and management of fiery ecosystems. Forest Ecology and Management 356: 5463. doi: 10.1016/j.foreco.2015.07.021

Fonda, R.W. 2001. Burning characteristics of needles from eight pine species. Forest Science 47: 390-396.

Gagnon, P.R., H.A. Passmore, W.J. Platt, J.A. Myers, C.E.T. Paine, and K.E. Harms. 2010. Does pyrogenicity protect burning plants? Ecology 91: 3481-3486. doi: 10.1890/10-0291.1

Gilliam, F.S., and W.J. Platt. 1999. Effects of long-term fire exclusion on tree species composition and stand structure in an old-growth Pinus palustris (longleaf pine) forest. Plant Ecology 140: 15-26. doi: 10.1023/A:1009776020438

Gotelli, N.J., and A.M. Ellison. 2013. A primer of ecological statistics. Second edition. Sinauer, Sunderland, Massachusetts, USA.

Grady, J.M., and W.A. Hoffman. 2012. Caught in a fire trap: recurring fire creates stable size equilibria in woody resprouters. Ecology 93: 2052-2060 doi: 10.1890/12-0354.1

Graves, S.J., S.W. Rifai, and F.E. Putz. 2014. Outer bark thickness decreases more with height on stems of fire-resistant than fire-sensitive Floridian oaks (Quercus spp.; Fagaceae). American Journal of Botany 101: 2183-2188. doi: 10.3732/ajb.1400412

Guerin, D.N. 1993. Oak dome clonal structure and fire ecology in a Florida longleaf pine dominated community. Bulletin of the Torrey Botanical Club 120: 107-114. doi: 10.2307/2996939

Guyette, R.P., R.M. Muzika, J. Kabrick, and M.C. Stambaugh. 2004. A perspective on Quercus life history characteristics and forest disturbance. Pages 138-142 in: M.A. Spetich, editor. Proceedings of the upland oak ecology symposium. USDA Forest Service General Technical Report GTR-SRS-73, Southern Research Station, Asheville, North Carolina, USA.

Hammond, D.H., J.M. Varner, J.S. Kush, and Z. Fan. 2015. Contrasting sapling bark allocation of five southeastern USA hardwood tree species in a fire prone ecosystem. Ecosphere 6(7): 112. doi: 10.1890/ES15-00065.1

Harrington, T.B. 2011. Overstory and understory relationships in longleaf pine plantations 14 years after thinning and woody control. Canadian Journal of Forest Research 41: 2301-2314. doi: $10.1139 / x 11-140$

Hiers, J.K., J.J. O'Brien, R.E. Will, and R.J. Mitchell. 2007. Forest floor depth mediates understory vigor in xeric Pinus palustris ecosystems. Ecological Applications 17: 806-814. doi: 10.1890/06-1015

Hiers, J.K., J.W. Walters, R.J. Mitchell, J.M. Varner, L.M. Conner, L. Blanc, and J. Stowe. 2014. Ecological value of retaining pyrophytic oaks in longleaf pine ecosystems. Journal of Wildlife Management 78: 383-393. doi: 10.1002/jwmg.676

Hoffmann, W.A., E.L. Geiger, S.G. Gotsch, D.R. Rossatto, L.C.R. Silva, O.L. Lau, M. Haridasan, and A.C. Franco. 2012. Ecological thresholds at the savanna-forest boundary: how plant traits, resources and fire govern the distribution of tropical biomes. Ecology Letters 15: 759768. doi: 10.1111/j.1461-0248.2012.01789.x

Jackson, J.F., D.C. Adams, and U.B. Jackson. 1999. Allometry of constitutive defense: a model and a comparative test with tree bark and fire regime. The American Naturalist 153: 614632. doi: 10.1086/303201

Jacqmain, E.I., R.H. Jones, and R.J. Mitchell. 1999. Influences of frequent cool-season burning across a soil moisture gradient on oak community structure in longleaf pine ecosystems. American Midland Naturalist 141: 85-100. doi: 10.1674/0003-0031(1999)141[0085: IOFCSB]2.0.CO;2 
Kane, J.M., J.M. Varner, and J.K. Hiers. 2008. The burning characteristics in Southeastern oaks: discriminating fire facilitators from fire impeders. Forest Ecology and Management 256: 2039-2045. doi: 10.1016/j.foreco.2008.07.039

Kaufman, L., and P.J. Rousseeuw. 2005. Finding groups in data: an introduction to cluster analysis. Wiley, Hoboken, New Jersey, USA.

Keeley, J.E., and P.H. Zedler. 1998. Evolution of life histories in Pinus. Pages 219-251 in: D.M. Richardson, editor. Ecology and biogeography of Pinus. Cambridge University Press, England, United Kingdom.

Kirkman, L.K., C.L. Brown, and D.J. Leopold. 2007. Native trees of the Southeast. Timber Press, Portland, Oregon, USA.

Kreye, J.K., J.M. Varner, J.K. Hiers, and J. Mola. 2013. Toward a mechanism for eastern North American forest mesophication: the role of litter drying. Ecological Applications 23: 19761986. doi: 10.1890/13-0503.1

Landers, J.L. 1991. Disturbance influences on pine traits in the southeastern United States. Proceedings of the Tall Timbers Fire Ecology Conference 17: 61-98.

Mitchell, R.J., J.K. Hiers, J.J. O’Brien, and G. Starr. 2009. Ecological forestry in the Southeast: understanding the ecology of fuels. Journal of Forestry 107: 391-397.

Mola, J.M., J.M. Varner, E.S. Jules, and T. Spector. 2014. Altered community flammability in Florida's Apalachicola ravines and implications for the persistence of the endangered conifer Torreya taxifolia. PLoS One 9: e103933. doi: 10.1371/journal.pone.0103933

Noss, R.F., W.J. Platt, B.A. Sorrie, A.S. Weakley, D.B. Means, J. Costanza, and R.K. Peet. 2015. How global biodiversity hotspots may go unrecognized: lessons from the North American Coastal Plain. Diversity and Distributions 21: 236-244. doi: 10.1111/ddi.12278

Nowacki, G.J., and M.D. Abrams. 2008. The demise of fire and "mesophication" of forests in the eastern United States. BioScience 58: 123-138. doi: 10.1641/B580207

Pecot, S.D., R.J. Mitchell, B.J. Palik, E.B. Moser, and J.K. Hiers. 2007. Competitive responses of seedlings and understory plants in longleaf pine woodlands: separating canopy influences above and below ground. Canadian Journal of Forest Research 37: 634-648. doi: 10.1139/X06-247

Peet, R.K. 2006. Ecological classification of longleaf pine woodlands. Pages 51-93 in: S. Jose, E.J. Jokela, and D.L. Miller, editors. The longleaf pine ecosystem: ecology, silviculture, and restoration. Springer, New York, New York, USA. doi: 10.1007/978-0-387-30687-2_3

Platt, W.J. 1999. Southeastern pine savannas. Pages 23-51 in: R.C. Anderson, J.S. Fralish, and J. Baskin, editors. The savanna, barren, and rock outcrop communities of North America. Cambridge University Press, England, United Kingdom. doi: 10.1017/ CBO9780511574627.003

Platt, W.J., and M.W. Schwartz. 1990. Temperate hardwood forests. Pages 194-229 in: R.L. Myers and J.J. Ewel, editors. Ecosystems of Florida. University Press of Florida, Gainesville, USA.

Robertson, K.M., and T.E. Ostertag. 2009. Biomass equations for hardwood resprouts in fire-maintained pinelands in the southeastern United States. Southern Journal of Applied Forestry 33: $121-128$.

Robertson, K.M., and T.L. Hmielowski. 2014. Effects of fire frequency and season on resprouting of woody plants in southeastern US pine-grassland communities. Oecologia 174: 765776. doi: 10.1007/s00442-013-2823-4

Romero, C., B.M. Bolker, and C.E. Edwards. 2009. Stem responses to damage: the evolutionary ecology of Quercus species in contrasting fire regimes. New Phytologist 182: 261-271. doi: 10.1111/j.1469-8137.2008.02733.x 
Rowe, J.S. 1983. Concepts of fire effects on plant individuals and species. Pages 135-154 in: R.W. Wein and D.A. MacLean, editors. The role of fire in northern circumpolar ecosystems. Wiley, Hoboken, New Jersey, USA.

Scholes, R.J., and S.R. Archer. 1997. Tree-grass interactions in savannas. Annual Review of Ecology and Systematics 28: 517-544. doi: 10.1146/annurev.ecolsys.28.1.517

Schwilk, D.W., and D.D. Ackerly. 2001. Flammability and serotiny as strategies: correlated evolution in pines. Oikos 94: 326-236. doi: 10.1034/j.1600-0706.2001.940213.x

Schwilk, D.W., M.S. Gaetani, and H.M. Poulos. 2013. Oak bark allometry and fire survival strategies in the Chihuahuan Desert Sky Islands, Texas, USA. PLoS One 8(11): e79825. doi: 10.1371/journal.pone.0079285

Smith, K.T., and E.K. Sutherland. 1999. Fire-scar formation and compartmentalization in oak. Canadian Journal of Forest Research 29: 166-171. doi: 10.1139/x98-194

Stambaugh, M.C., R.P. Guyette, and J.M. Marschall. 2011. Longleaf pine (Pinus palustris Mill.) fire scars reveal new details of a frequent fire regime. Journal of Vegetation Science 22: 1094-1104. doi: 10.1111/j.1654-1103.2011.01322.x

Stambaugh, M.C., J.M. Varner, R.F. Noss, D.C. Dey, N. Christensen, R.F. Baldwin, R.P. Guyette, B. Hanberry, C. Harper, S. Lindblom, and T. Waldrop. 2015. Clarifying the role of fire in the Eastern deciduous forest: reply to Matlack. Conservation Biology 29: 942-946. doi: 10.1111/ cobi.12473

Trauernicht, C., B.P. Murphy, T.E. Portner, and D.M.J.S. Bowman. 2012. Tree cover-fire interactions promote the persistence of a fire-sensitive conifer in a highly flammable savanna. Journal of Ecology 100: 958-968. doi: 10.1111/j.1365-2745.2012.01970.x

Van Lear, D.H., and P.H. Brose. 2002. Fire and oak management. Pages 269-279 in: W.J. McShea and W.M. Healy, editors. Oak forest ecosystems - ecology and management for wildlife. Johns Hopkins University Press, Baltimore, Maryland, USA.

Varner, J.M., D.R. Gordon, F.E. Putz, and J.K. Hiers. 2005. Restoring fire to long-unburned Pinus palustris ecosystems: novel fire effects and consequences for long-unburned ecosystems. Restoration Ecology 13: 536-544. doi: 10.1111/j.1526-100X.2005.00067.x

Varner, J.M., J.M. Kane, J.K. Kreye, and E. Engber. 2015a. The flammability of forest and woodland litter: a synthesis. Current Forestry Reports 1: 91-99. doi: 10.1007/s40725-015-0012-x

Varner, J.M., J.M. Kane, E.M. Banwell, and J.K. Kreye. 2015b. Flammability of litter from Southeastern trees: a preliminary assessment. Pages 183-187 in: A.G. Holley, K.F. Connor, and J.P. Haywood, editors. Proceedings of the 17th Biennial Southern Silvicultural Research Conference. USDA Forest Service General Technical Report e-GTR-SRS-203, Southern Research Station, Asheville, North Carolina, USA.

Vázquez, A., B. Perez, F. Fernández-González, and J.M. Moreno. 2002. Recent fire regime characteristics and potential natural vegetation relationships in Spain. Journal of Vegetation Science 13: 663-676. doi: 10.1111/j.1654-1103.2002.tb02094.x

Veldman, J.W., W.B. Mattingly, and L.A. Brudvig. 2013. Understory plant communities and the functional distinction between savanna trees, forest trees, and pines. Ecology 94: 424-434. doi: 10.1890/12-1019.1

Ware, S., C.C. Frost, and P.D. Doerr. 1993. Southern mixed hardwood forest: the former longleaf pine forest. Pages 447-493 in: W.H. Martin, S.G. Boyce, and A.C. Echternacht, editors. Biodiversity of the southeastern United States: lowland terrestrial communities. Wiley, Hoboken, New Jersey, USA. 
Appendix 1. Principal Components Analysis factor loadings. Data sources for each trait are reported in Table 1. Traits in bold were used in the full trait analysis and in the subsequent eight-species analysis.

\begin{tabular}{lcc}
\hline & \multicolumn{2}{c}{ Flammability traits $(\boldsymbol{n}=\mathbf{7})$} \\
\hline Variable & Factor $\mathbf{1}$ & Factor 2 \\
\hline flame height & -0.96 & 0.06 \\
flame time & 0.95 & -0.19 \\
smolder time & -0.34 & -0.72 \\
fuel consumed & -0.84 & -0.44 \\
drying time & 0.72 & -0.58 \\
moisture capacity & -0.36 & -0.48 \\
litter depth & -0.98 & 0.14 \\
\hline Variation explained $(\%)$ & 60.85 & 19.21 \\
\hline
\end{tabular}

\begin{tabular}{|c|c|c|c|}
\hline \multicolumn{4}{|c|}{ Protective traits $(n=9)$} \\
\hline Variable & Factor 1 & Factor 2 & \\
\hline rhytidome & -0.90 & -0.23 & \\
\hline phloem coefficient & -0.45 & -0.38 & \\
\hline sapling rhytidome & 0.97 & 0.25 & \\
\hline wound closure & 0.76 & -0.45 & \\
\hline xylem lost & -0.98 & $<0.01$ & \\
\hline xylem decay & -0.84 & 0.35 & \\
\hline bark rhytidome thick & 0.96 & 0.16 & \\
\hline inner bark rhytidome & -0.18 & 0.92 & \\
\hline mature height & -0.85 & -0.04 & \\
\hline Variation explained $(\%)$ & 65.15 & 16.14 & \\
\hline \multicolumn{4}{|c|}{ Physiological traits $(n=17)$} \\
\hline Variable & Factor 1 & Factor 2 & Factor 3 \\
\hline leaf lifespan & -0.99 & -0.03 & -0.03 \\
\hline canopy duration & -0.88 & 0.20 & -0.34 \\
\hline laminar leaf area & 0.66 & 0.10 & 0.09 \\
\hline SLA & 0.90 & 0.08 & 0.17 \\
\hline $\mathbf{A}_{\max }$ & -0.68 & 0.37 & 0.61 \\
\hline $\mathbf{A}_{\text {mass }}^{\text {max }}$ & 0.24 & 0.41 & 0.85 \\
\hline leaf $\mathbf{N}(\%)$ & 0.86 & 0.25 & 0.40 \\
\hline leaf chlorophyll & -0.53 & 0.26 & 0.41 \\
\hline seed mass & 0.41 & -0.53 & 0.51 \\
\hline $\max \mathrm{Ks}$ & 0.32 & 0.78 & -0.41 \\
\hline transpiration & 0.63 & 0.67 & 0.17 \\
\hline Huber & -0.87 & -0.33 & 0.32 \\
\hline conductivity loss & -0.20 & 0.92 & 0.19 \\
\hline wood density & -0.80 & 0.08 & 0.54 \\
\hline radial growth increment & 0.25 & 0.73 & -0.30 \\
\hline seedling AGR & 0.08 & 0.88 & -0.15 \\
\hline seedling RGR & -0.76 & 0.39 & -0.06 \\
\hline Variation explained (\%) & 42.18 & 24.98 & 15.09 \\
\hline
\end{tabular}

